\title{
АНАЛІЗ ДОСВІДУ ВИКОРИСТАННЯ ПРОТОКОЛІВ НАДАННЯ МЕДИЧНОЇ ДОПОМОГИ У НАВЧАЛЬНОМУ ПРОЦЕСІ ПРИ ВИКЛАДАННІ ВНУТРІШНЬОЇ МЕДИЦИНИ У СТУДЕНТІВ 5 КУРСУ МЕДИЧНОГО ФАКУЛЬТЕТУ
}

\author{
О. В. Курята, К. Г. Карапетян, О. Ю. Філіппова, Н. І. Бардаченко \\ ДЗ “Дніпропетровськамедична академія МОЗ Украӥни”
}

\section{ANALYSIS OF THE EXPERIENCE OF USING MEDICAL CARE PROTOCOLS IN THE LEARNING PROCESS OF INTERNAL MEDICINE FOR THE $5^{\text {TH }}$ YEAR STUDENTS IN MEDICAL FACULTY}

\author{
O. V. Kuryata, K. H. Karapetyan, O. Yu. Filippova, N. I. Bardachenko \\ SI "Dnipropetrovsk Medical Academy of MPH of Ukraine"
}

\begin{abstract}
Стаття розкриває досвід кафедри госпітальної терапії № 1 та профпатології у використанні в освітньому процесі протоколів надання медичної допомоги у підготовці майбутніх лікарів загальної практики у системі вищих медичних закладів.
\end{abstract}

The article reveals the experience of the Department of Hospital Therapy №1 and occupational diseases in the usage of medical protocols care during the educational process in learning of future general practitioners in the system of higher medical institutions.

Вступ. Формування професійних якостей студента як гармонійної особистості є невід'ємною складовою частиною вищої медичної освіти. Зростання вимог до якості підготовки майбутніх лікарів загальної практики на сьогоднішньому етапі згідно з вимогами світової вищої медичної освіти передбачає впровадження у навчальний процес різноманітних методів засвоєння матеріалу [1].

Необхідність озброєння майбутніх спеціалістів різноманітними комплексами професійних умінь для реалізації їх виробничої діяльності $є$ одним із пріоритетних завдань вищої медичної підготовки $[2,3]$. У контексті Болонського процесу має місце уніфікація навчального процесу при використанні різноманітних форм навчання, спрямованих на максимальну реалізацію активності, ініціативності та самостійності студентів [4]. Особливо слід підкреслити роль у навчальному процесі джерел інформації. У наш час завдяки науково-технічному прогресу збільшення інформаційних потоків відбувається постійно та з великою наростаючою силою. Одержання інформації, яку опрацьовують студенти на практичних заняттях під час самостійної роботи, відбувається з багатьох джерел: підручників, довідників, каталогів, конспектів лекцій, періодичних фахових видань, Інтернету.
Створені на сьогодні накази MO3 і затверджені ними клінічні протоколи визначають вимоги до діагностичних, лікувальних, профілактичних та реабілітаційних методів надання медичної допомоги й допомагають у практиці лікарів і в підготовці майбутніх фахівців загальної практики. Медико-організаційні технології протоколів надання медичної допомоги базуються на висновках доказової медицини, рекомендаціях ВОО3, міжнародному та вітчизняному досвіді [5]. Протоколи відображають державну політику, що проводиться в Україні в галузі охорони здоров'я з урахуванням існуючих законодавчих актів та $€$ для медичних спеціалістів засобом підтримки надання високої якості спеціалізованої медичної допомоги в терапевтичних закладах усіх рівнів [6].

Основна частина. Для покращення навчального процесу за кредитно-модульною системою на кафедрі госпітальної терапії № 1 та профпатології ДЗ "Дніпропетровська медична академія МОЗ України", окрім мультимедійних презентацій лекцій та методичного забезпечення, використовується ознайомлення студентів 5 курсів медичних факультетів 3 протоколами надання медичної допомоги згідно 3 наказами МОЗ України, а також проводиться аналіз можливості студентів користуватися комп'ютерни-

() О. В. Курята, К. Г. Карапетян, О. Ю. Філіппова, Н. І. Бардаченко 
ми та інтернет-технологіями. Клінічні протоколи студенти розглядали як додаткову інформацію, яка не може повністю замінити навчальні підручники, методичні розробки та лекційний матеріал, а може лише доповнювати їх. Студенти 5 курсу раніше, після закінчення 4 курсу, вже проходили практику у стаціонарах і мають досвід роботи з протоколами надання медичної допомоги. За допомогою протоколів ми намагаємося надати майбутнім спеціалістам загальної практики інформацію про стандартизовані методи роботи клініциста та використання їх на практиці у лікувальних закладах різних рівнів акредитаціі. Такий підхід, на нашу думку, наближує студентів до вимог майбутньої роботи, надає їм орієнтири для праці під час літньої виробничої практики. До того ж, слід прийняти до уваги, що національні підручники 3 клінічних дисциплін використовуються тривалий час, тому розділи про діагностику та лікування потребують доповнення та корекції, що частково може бути здійснено за рахунок вивчення клінічних протоколів.

Для забезпечення формування у студентів медичних факультетів нового типу клінічного мислення колектив кафедри вважає надзвичайно важливим застосування нових педагогічних підходів до ведення практичних занять. Викладачами кафедри була розроблена форма анкетування вітчизняних студентів 5 курсу медичних факультетів, яка висвітлює відношення майбутніх фахівців до комп'ютерних та інтернет-технологій, а також розкриває можливості використання протоколів надання медичної допомоги за змістовими модулями з кардіологіі, ревматології і нефрології у навчальному процесі при підготовці до практичних занять.

Анкетування пройшли 139 вітчизняних студентів медичних факультетів, з них 112 (80,6 \%) навчаються на бюджеті, 27 (19,4%) - на позабюджетному навчанні. Власний комп'ютер із власним доступом до Інтернету мають практично усі студенти: 97,3 \% студентів на бюджеті та 88,9 \% на платному навчанні (табл. 1). Крім того, у медичній академії на кафедрах та в читальному залі медичної бібліотеки створені усі умови для роботи студентів на комп'ютерах 3 доступом до Інтернету. Аналізуючи дані, для навчання комп'ютером користуються 90 (80,4 \%) студентів бюджетної форми навчання та 18 (66,7 \%) позабюджетної форми навчання. Ці дані демонструють значне зростання використання комп'ютерів у роботі студентів порівняно $з$ попереднім дослідженням питання 5 років тому. Для написання навчальних історій хвороб студенти обох факультетів комп'ютер не використовують. У більшості випадків студенти працюють на комп'ютері з базами тестів “Крок-2”: 89 (79,4 \%) студентів на бюджеті та 14 (51,9\%) на позабюджетному навчанні. Для роботи з протоколами надання медичної допомоги комп'ютером користуються лише студенти, які проходять навчання на бюджеті - 80 (71,4 \%). 18 (66,7 \%) студентів медичних факультетів на позабюджетному навчанні комп'ютер для роботи з протоколами використовують дуже рідко, про що свідчать дані в таблиці 1. На думку студентів обох факультетів, щоденний контроль знань слід проводити методом опитування викладачем. 3 цим погодились 92 (82,1\%) студенти на бюджеті та 23 $(85,2$ \%) студенти на позабюджетному навчанні.

Відношення студентів медичних факультетів до протоколів надання медичної допомоги, які затверджені МОЗ України, мало деякі відмінності залежно від форми їхнього навчання (табл. 2). Студенти, які навчаються на бюджеті, в подальшому будуть працювати лікарями загальної практики та сімейної медицини, тому їх думка має більш оформлений характер. За результатами анкетування, 72 (64,3 \%) студенти, які навчаються на бюджеті, та 12 (44,4%) студентів на позабюджетному навчанні вважали протоколи необхідними тільки для роботи лікаря. Необхідність протоколів для студентів підтримали лише 26 (23,2 \%) та 6 (22,2 \%) студентів відповідно. В більшості випадків при підготовці до практичних занять з протоколами працювати можна, про що зазначили 82 (73,2 \%) студенти на бюджеті та 16(59,3 \%) на позабюджетному навчанні. Для підготовки до практичних занять протоколи декілька разів на тиждень використовують 53 (47,3 \%) студенти бюджетної форми навчання проти 10 (37,1%) студентів позабюджетної форми навчання. Майже половина 55 (49,1 \%) студентів на бюджеті задоволена протоколами надання медичної допомоги в якості підготовки до практичних занять, коли 18 (66,7 \%) студентів на позабюджетному навчанні мають нейтральне відношення до протоколів при підготовці до занять. 70 (62,5 \%) студентів на бюджеті та 12 (44,4 \%) на позабюджетному навчанні вважають протоколи лише невеликим поліпшенням при підготовці занять порівняно $з$ тим, що вже представлено в навчальних посібниках. Слід відмітити, що в майбутньому користуватися протоколами надання медичної допомоги при підготовці до практичних занять планує більшість студентів на бюджеті 75 (67 \%) та 12 (44,4 \%) на позабюджетному навчанні. За корисність протоколів 40 (35,7 \%) студентів на бюджеті та 12 (44,4 \%) на позабюджетному навчанні, за зручність протоколів 43 (38,4 \%) на бюджеті та $10(37,1$ \%) на позабюджетному навчанні. 
Таблиця 1. Користування студентами медичних факультетів комп’ютерними та інтернет-технологіями

\begin{tabular}{|c|c|c|c|c|}
\hline Варіанти відповідей & \multicolumn{2}{|c|}{$\begin{array}{c}\text { Бюджетне навчання } \\
112(80,6 \text { \%) } \\
\text { студентів }\end{array}$} & \multicolumn{2}{|c|}{$\begin{array}{c}\text { Позабюджетне } \\
\text { навчання } \\
27(19,4 \text { \%) } \\
\text { студентів }\end{array}$} \\
\hline \multicolumn{5}{|c|}{ Чи є у Вас доступ до комп’ютера? } \\
\hline 1. Так & 112 & $100 \%$ & 27 & $100 \%$ \\
\hline \multicolumn{5}{|c|}{ Чи є у Вас доступ до Інтернету? } \\
\hline 1. Власний & 109 & $97,3 \%$ & 26 & $88,9 \%$ \\
\hline 2. Немає доступу & 3 & $2,7 \%$ & 1 & $3,7 \%$ \\
\hline \multicolumn{5}{|c|}{ Ви користуєтесь комп’ютером? } \\
\hline 1. Для навчання & 90 & $80,4 \%$ & 18 & $66,7 \%$ \\
\hline 2. Для відпочинку & 13 & $11,6 \%$ & 3 & $11,1 \%$ \\
\hline 3. Для роботи & 5 & $4,5 \%$ & 5 & $18,5 \%$ \\
\hline 4. Для спілкування & 4 & $3,5 \%$ & 1 & $3,7 \%$ \\
\hline \multicolumn{5}{|c|}{ Чи пишете Ви навчальні історії хвороб на комп’ютері? } \\
\hline 1. Завжди & 8 & $7,1 \%$ & 1 & $3,7 \%$ \\
\hline 2. На окремих кафедрах & 20 & $17,9 \%$ & 19 & $70,4 \%$ \\
\hline 3. Ніколи & 84 & $75 \%$ & 7 & $25,9 \%$ \\
\hline \multicolumn{5}{|c|}{$\begin{array}{l}\text { Чи використовуєте Ви комп’ютер для роботи з протоколами надання медичної допомоги, які затверджені } \\
\text { наказами МОЗ України? }\end{array}$} \\
\hline 1. Регулярно & 80 & $71,4 \%$ & 5 & $18,5 \%$ \\
\hline 2. Рідко & 30 & $26,8 \%$ & 18 & $66,7 \%$ \\
\hline 3. Не використовую & 2 & $1,8 \%$ & 4 & $14,8 \%$ \\
\hline \multicolumn{5}{|c|}{ На Вашу думку, протоколи надання медичної допомоги за спеціальністю: } \\
\hline 1. Необхідні для роботи лікаря & 72 & $64,3 \%$ & 12 & $44,4 \%$ \\
\hline 2 Необхідні для підготовки студента & 26 & $23,2 \%$ & 6 & $22,2 \%$ \\
\hline 3. Для навчання достатньо підручника & - & - & 1 & $3,7 \%$ \\
\hline $\begin{array}{l}\text { 4. Стандарти не потрібні, тому що це шаблони, а робота } 3 \\
\text { хворим має бути індивідуальна }\end{array}$ & 14 & $12,5 \%$ & 8 & $29,6 \%$ \\
\hline
\end{tabular}

Незважаючи на вищенаведені дані, більшість студентів обох форм навчання вважає, що викладач повинен контролювати знання студентами протоколів надання медичної допомоги під час проведення практичних занять, про що написали 83 (74,1%) студенти на бюджеті та 21 (77,8 \%) на позабюджетному навчанні.

Отже, використання у навчальному процесі протоколів надання медичної допомоги має хорошу результативність та допомагає майбутнім лікарям загальної практики у засвоєнні знань і формуванні вмінь, розвиває навчальну і практичну діяльність. На наш погляд, з урахуванням матеріалів опитування та використання комп'ютерів у практиці сучасного лікаря, слід більш активно застосовувати комп'ютерні технології задля написання навчальних історій хвороб.

За кредитно-модульною системою організація навчального процесу на кафедрі госпітальної терапії
№ 1 та профпатологіï, сучасне методичне забезпечення, мультимедійні презентації лекцій, що використовуються в межах традиційної системи управління якістю підготовки майбутніх лікарів та ознайомлення студентів 5 курсу 3 клінічними протоколами надання медичної допомоги, вирішують більшість проблем та сприяють усвідомленому оволодінню студентами знаннями та уміннями, необхідними для їх майбутньої професійної діяльності, а також забезпечують формування реалістичних поглядів на майбутню практичну діяльність в якості лікарів загальної практики.

Висновки: 1. Наявність практично 100 \% забезпеченості комп'ютерами та персональним доступом до Інтернету студентів старших курсів створює умови для більш широкого використання комп'ютерних технологій у навчальному процесі. 
Таблиця 2. Відношення студентів медичних факультетів до стандартів діагностики та лікування

\begin{tabular}{|c|c|c|c|c|}
\hline Варіанти відповідей & \multicolumn{2}{|c|}{$\begin{array}{c}\text { Бюджетне } \\
\text { навчання } \\
112(80,6 \%) \\
\text { студентів }\end{array}$} & \multicolumn{2}{|c|}{$\begin{array}{c}\text { Позабюджетне } \\
\text { навчання } \\
27(19,4 \%) \\
\text { студентів }\end{array}$} \\
\hline \multicolumn{5}{|c|}{ Чи легкі для сприйняття Вами протоколи надання медичної допомоги? } \\
\hline 1. Вони ясні та зрозумілі, працювати з ними легко & 28 & $25 \%$ & 9 & $33,3 \%$ \\
\hline 2. Не все зрозуміло, але в цілому працювати можна & 82 & $73,2 \%$ & 16 & $59,3 \%$ \\
\hline $\begin{array}{l}\text { 3. Для студента багато чого не зрозуміло, краще на } 5 \text { курсі їх не } \\
\text { розглядати }\end{array}$ & 2 & $1,8 \%$ & 2 & $7,4 \%$ \\
\hline \multicolumn{5}{|c|}{ Як часто Ви використовуєте протоколи надання медичної допомоги для підготовки до практичних занять? } \\
\hline 1. Щоденно & 27 & $24,1 \%$ & 6 & $22,2 \%$ \\
\hline 2. Декілька разів на тиждень & 53 & $47,3 \%$ & 10 & $37,1 \%$ \\
\hline 3. Один раз на тиждень & 6 & $5,4 \%$ & 3 & $11,1 \%$ \\
\hline 4. Декілька разів на місяць & 17 & $15,1 \%$ & 5 & $18,5 \%$ \\
\hline 5. Декілька разів на рік & 4 & $3,6 \%$ & 2 & $7,4 \%$ \\
\hline 6. Не використовую & 5 & $4,5 \%$ & 1 & $3,7 \%$ \\
\hline \multicolumn{5}{|c|}{ Чи задоволені Ви протоколами надання медичної допомоги з метою підготовки до практичних занять? } \\
\hline 1. Дуже задоволений & 1 & $0,9 \%$ & 2 & $7,4 \%$ \\
\hline 2. Задоволений & 55 & $49,1 \%$ & 6 & $22,2 \%$ \\
\hline 3. Нейтрально & 48 & $42,9 \%$ & 18 & $66,7 \%$ \\
\hline 4. Дуже незадоволений & 8 & $7,1 \%$ & 1 & $3,7 \%$ \\
\hline \multicolumn{5}{|c|}{$\begin{array}{c}\text { Чи будете Ви продовжувати користуватися протоколами надання медичної допомоги в майбутньому при } \\
\text { підготовці до практичних занять? } \\
\end{array}$} \\
\hline 1. Регулярно & 75 & $67 \%$ & 12 & $44,4 \%$ \\
\hline 2. Інколи & 27 & $24,1 \%$ & 12 & $44,4 \%$ \\
\hline 3. Hi & - & - & - & - \\
\hline 4. Не впевнений & 10 & $8,9 \%$ & 3 & $11,1 \%$ \\
\hline \multicolumn{5}{|c|}{$\begin{array}{c}\text { Яке з наведених тверджень найкраще відповідає Вашій потребі при користуванні протоколами надання } \\
\text { медичної допомоги? }\end{array}$} \\
\hline $\begin{array}{l}\text { 1. Стандарти обстеження та лікування мені потрібні, тому що це єдиний } \\
\text { спосіб підготовки до практичних занять }\end{array}$ & 17 & $15,2 \%$ & 2 & $7,4 \%$ \\
\hline $\begin{array}{l}\text { 2. Це лише невелике поліпшення при підготовці занять порівняно з тим, } \\
\text { що вже надано в навчальних посібниках }\end{array}$ & 70 & $62,5 \%$ & 12 & $44,4 \%$ \\
\hline $\begin{array}{l}\text { 3. Це практично те ж саме, що представлено в навчальних посібниках, } \\
\text { методичних рекомендаціях }\end{array}$ & 11 & $9,8 \%$ & 7 & $26 \%$ \\
\hline $\begin{array}{l}\text { 4. Мене більше влаштовує те, що представлено в навчальних посібниках } \\
\text { та методичних рекомендаціях }\end{array}$ & 13 & $11,6 \%$ & 6 & $22,2 \%$ \\
\hline $\begin{array}{l}\text { 5. Не бачу жодного сенсу у їх використанні для підготовки до практичних } \\
\text { занять }\end{array}$ & 1 & $0,9 \%$ & - & - \\
\hline \multicolumn{5}{|c|}{$\begin{array}{c}\text { Які з перерахованих факторів здатні найбільше вплинути на Ваше рішення використовувати протоколи } \\
\text { надання медичної допомоги для підготовки до практичних занять? }\end{array}$} \\
\hline 1. Корисність & 40 & $35,7 \%$ & 12 & $44,4 \%$ \\
\hline 2. Зручність & 43 & $38,4 \%$ & 10 & $37,1 \%$ \\
\hline 3. Простота & 21 & $18,8 \%$ & 4 & $14,8 \%$ \\
\hline 4. Не знаю & 8 & $7,1 \%$ & 1 & $3,7 \%$ \\
\hline \multicolumn{5}{|c|}{ Знання студентом протоколів надання медичної допомоги треба контролювати: } \\
\hline 1. Під час практичних занять & 83 & $74,1 \%$ & 21 & $77,8 \%$ \\
\hline 2. Лише на заключному заліку & 12 & $10,7 \%$ & 2 & $7,4 \%$ \\
\hline 3. Під час проходження поліклінічної практики & 7 & $6,3 \%$ & 1 & $3,7 \%$ \\
\hline 4. Ваш варіант відповіді & 10 & $8,9 \%$ & 3 & $11,1 \%$ \\
\hline
\end{tabular}




\section{ВДОСКОНАЛЕННЯ ВИЩОЇ МЕДИЧНОЇ ОСВІТИ}

2. Використання у навчальному процесі національних стандартів діагностики та лікування у вигляді затверджених МОЗ клінічних протоколів надає студентам досвід роботи в системі охорони здоров’я.

\section{Література}

1. Горшунова Н. К. Инновационные технологии в подготовке врача в системе непрерывного профессионального образования / Н. К. Горшунова // Фундаментальные исследования. -2009 .-№ 2.-С. 86-88.

2. Инновационный менеджмент : учебник для вузов / под ред. С. Д. Ильенковой.-М. : ЮНИТИ, 2001.-327 с.

3. Кукуев А. И. Современные подходы в образовании : учебно-методическое пособие / А. И. Кукуев, В. А. Шевченко. - Ростов-на-Дону : ИПОПИЮФУ, 2010. -55 с.

4. Пидаев А. В. Болонский процесс в Европе / А. В. Пидаев, В. Г. Передерий. - Одесса : Одес. гос. ун-т, 2004. - 192 с.

5. Про затвердження Уніфікованої методики з розробки клінічних настанов, медичних стандартів, уніфікованих клінічних протоколів медичної допомоги, локальних протоколів медичної допомоги (клінічних маршрутів пацієнтів)
3. Використання сучасних національних клінічних протоколів у навчанні студентів надає можливість скоротити розрив між змістом посібників, що працюють тривалий час (у розділі діагностики та лікування) та сучасним рівнем медицини.

назасадах доказової медицини (частина перша) (2009) [Електронний ресурс]. - Режим доступу до докум.: http:// triton.moz.gov.ua/ua/main/docs/?docID=12078 - Назва з екрана. - (Нормативний документ Міністерства охорони здоров'я України. Наказ).

6. Про затвердження Уніфікованої методики з розробки клінічних настанов, медичних стандартів, уніфікованих клінічних протоколів медичної допомоги, локальних протоколів медичної допомоги (клінічних маршрутів пацієнтів) на засадах доказової медицини (частина друга) [Електронний ресурс]. - Режим доступу до докум.: http:// www.moz.gov.ua/ua/main/docs/?docID=13988 - Назва 3 екрана. - (Нормативний документ Міністерства охорони здоров'я та Академії медичних наук України. Наказ).

Отримано 05.06.14 